\title{
INTERNALISASI NILAI-NILAI AGAMA PADA ANAK USIA DINI DI RAUDHATHUL ATFHAL PERWANIDA 1 LIPU KABUPATEN MAJENE
}

\author{
The Internalization of Religious Values into Pre School in Raudhatul Atfhal Perwanida \\ 1 Lipu Majene Regency
}

\author{
Amiruddin \\ Balai Penelitian dan Pengembangan Agama Makassar \\ Jl. A.P Pettarani No. 72 Makassar \\ Email: amiruddinalbarru@yahoo.co.id
}

Naskah diterima tanggal 11 Desember 2013. Naskah direvisi tanggal 18 Maret 2014. Naskah disetujui tanggal 3 April 2014

\begin{abstract}
Abstrak
Penelitian ini bertujuan untuk mengungkap bentuk-bentuk pembelajaran nilai agama pada anak usia dini di RA Perwanida 1 Lipu. Masalah yang diangkat dalam penelitian ini adalah "bagaimana bentukbentuk pembelajaran nilai agama pada anak usia dini di RA Perwanida 1 Lipu?" Berkenaan dengan masalah tersebut, penulis menggunakan metode penelitian kualitatif dengan teknik pengumpulan data berupa wawancara, observasi, dan studi dokumentasi. Data dalam penelitian ini berupa penelusuran dokumentasi dalam bentuk Rencana Kegiatan Harian (RKH), Rencana Kegiatan Mingguan (RKM), program semester, dan program tahunan. Hasil penelitiani ini menunjukkan bahwa implementasi pembelajaran nilai agama pada anak usia dini di RA Perwanida 1 Lipu dituangkan dalam proses pembelajaran yang mencakup tiga kegiatan, yaitu kegiatan awal, inti, dan kegiatan penutup.
\end{abstract}

Kata kunci: anak usia dini, kurikulum, metode pembelajaran, sistem evaluasi, nilai-nilai agama

\begin{abstract}
This research aimed at revealing the learning styles of religious value in preschool at Raudhatul Atfhal Perwanida 1 Lipu. The research problem issued was "how is the learning styles of religious value in pre school?" based on the research problem, the researcher applied qualitative research which collected the data through interview, observation, and documentation study. The data of this research were the investigation of documentations in form of daily activities plan, weekly activities plan, dually program, and annually program. The result of this research shows that the learning implementations of religious value into preschool children in RA Perwanida 1 Lipu were formed in the learning process covering three activities, such as beginning, main, and closing activities.
\end{abstract}

Keywords: pre-school, curriculum, learning method, evaluation system, religious values

\section{PENDAHULUAN}

U ndang-Undang Nomor 20 tahun 2003 tentang Sistem Pendidikan Nasional Pasal 1 ayat 4 menyatakan bahwa Pendidikan Anak Usia Dini (PAUD) adalah suatu upaya pembinaan yang ditujukan kepada anak sejak lahir sampai dengan usia enam tahun yang dilakukan melalui pemberian rangsangan pendidikan untuk membantu pertumbuhan dan perkembangan jasmani dan rohani agar anak memiliki kesiapan dalam memasuki pendidikan lebih lanjut.

Anak merupakan investasi yang sangat penting bagi penyiapan sumber daya manusia (SDM) di masa depan. Dalam rangka mempersiapakan SDM yang berkualitas untuk masa depan, pendidikan merupakan salah satu hal yang penting untuk diberikan sejak usia dini. Memberikan perhatian 
yang lebih kepada anak usia dini untuk mendapatkan pendidikan, merupakan salah satu langkah yang tepat untuk menyiapkan generasi unggul yang akan meneruskan perjuangan bangsa. Usia dini merupakan masa keemasan (golden age) yang hanya terjadi satu kali dalam perkembangan kehidupan manusia. Masa ini sekaligus merupakan masa yang kritis dalam perkembangan anak. Jika pada masa ini anak kurang mendapat perhatian dalam hal pendidikan, perawatan, pengasuhan dan layanan kesehatan serta kebutuhan gizinya dikhawatirkan anak tidak dapat tumbuh dan berkembang secara optimal (Murdiono, 2009:3).

Salah satu bagian penting yang harus mendapatkan perhatian terkait dengan pendidikan yang diberikan sejak usia dini adalah penanaman nilai moral melalui pendidikan di Raudhatul Athfal (RA). Pendidikan nilai dan moral yang dilakukan sejak usia dini, diharapkan pada tahap perkembangan selanjutnya anak akan mampu membedakan baik buruk, benar salah, sehingga ia dapat menerapkannya dalam kehidupan seharihari. Hal itu akan berpengaruh pada mudah tidaknya anak diterima oleh masyarakat sekitarnya dalam hal bersosialisasi. Pendidikan dan bimbingan akhlak di Raudhatul Atfhal diprogramkan dalam pengembangan sikap dan prilaku yang mencakup, 1) Rumpun pengembangan moral dan nilai-nilai agama, 2) Rumpun pengembangan sosial dan emosiaonal (http://repository.upi.edu/operator/ upload.pdf).

Dalam membimbing dan mengembangkan potensi anak usia dini perlu memilih metode yang tepat. Untuk itulah guru atau pendidik TK/RA harus pandai dalam memilih dan menentukan metode yang akan digunakan untuk menanamkan nilai-nilai agama anak agar pesan moral yang ingin disampaikan guru dapat benar-benar sampai dan dipahami oleh anak untuk bekal kehidupannya di masa depan. Pemahaman yang dimiliki guru atau pendidik akan mempengaruhi keberhasilan menanaman nilai-nilai agama anak secara optimal.

Penelitian yang telah dilakukan oleh Rantina (2012:10) dengan temuan bahwa pembelajaran agama di sentra iman dan taqwa di Taman Kanakkanak Huffazh Payakumbuh yang digunakan sudah mengacu dan sesuai dengan perkembangan anak. Pembelajaran agama khususnya disentra Dienul Islam tidak hanya menghadirkan dunia nyata di dalam pembelajaran tetapi mengarahkan anak ke agama. Pembelajaran agama khususnya disentra Dienul Islam mengajarkan anak untuk mengenal agama lebih mendalam.
Sementara itu, pertanyaan penelitian yang ingin dijawab melalui penelitian ini adalah bagaimana metode penanaman nilai-nilai agama di Raudhatul Atfhal Perwanida 1 Lipu Kabupaten Majene melalui kurikulum, metode/model pembelajaran dan sistem evaluasi?

Bertolak dari rumusan permasalahan tersebut, tujuan yang ingin dicapai dalam penelitian ini adalah terungkapnya bentuk-bentuk pembelajaran nilai agama pada anak usia dini di RA Perwanida 1 Lipu melalui komponen pendidikan yaitu kurikulum, metode, dan sistem evaluasi.

\section{Tinjauan Pustaka}

Pendidikan Anak Usia Dini (PAUD) adalah suatu upaya pembinaan yang ditujukan kepada anak sejak lahir sampai usia enam tahun yang dilakukan melalui pemberian rangsangan pendidikan untuk membantu pertumbuhan dan perkembangan jasmani dan rohani anak sebagai persiapan unuk hidup dan dapat menyesuaikan diri dengan lingkungannya serta memiliki kesiapan untuk memasuki kehidupan selanjutnya (Direktorat Jenderal Pendidikan Islam, Direktorat Pendidikan Madrasah, 2011:3). Oleh karena itu, pendidikan anak usia dini merupakan pondasi bagi dasar kepribadian anak. Anak yang mendapat pembinaan sejak usia dini akan meningkatkan kesehatan dan kesejahteraan mental dan fisik, yang akan berdampak pada peningkatan prestasi belajar, etos kerja, dan produktivitas. Pada akhirnya anak akan lebih mampu untuk mandiri dan mengoptimalkan potensi yang dimiliki (http://repository.upi.edu/ operator/upload/t_pendas_0808974_chapter2.pdf.)

Operasionalisasi dan formulasi pelaksanaan pendidikan agama Islam dilakukan dalam bentuk mata pelajaran yang disebut Pendidikan Agama Islam (PAI). Perumusan PAI dibuat dalam bentuk bidang pengembangan. Terdapat lima bidang pengembangan pada PAUD yaitu: Pengembangan Agama Islam, pengembangan bahasa, pengembangan fisik-motorik, pengembangan sains, dan pengembangan seni dan keterampilan. Pengembangan Agama Islam tersebut berlangsung secara utuh pada lembaga pendidikan keagamaan seperti Raudhatul Athfal/Bustanul Athfal (RA/ BA), TK Islam/TK Islam Terpadu, TK Al-Quran, dan berbagai lembaga pendidikan keagamaan yang tumbuh di masyarakat.

Secara yuridis, pelaksanaan pendidikan agama Islam pada pendidikan anak usia dini mengacu 
pada konstitusi dan regulasi peraturan hukum yang mendukung, antara lain:

1. Amandemen Undang-Undang Dasar 1945, yaitu a) Pasal 28 b ayat (2) setiap anak berhak atas kelangsungan hidup, tumbuh dan berkembang serta berhak atas perlindungan dari kekerasan dan diskriminasi, b) Pasal 31 ayat (1) setiap warga negara berhak mendapat pendidikan, c) Pasal 31 ayat (2) setiap warga negara wajib mengikuti pendidikan dasar dan pemerintah wajib membiayainya, e) Pasal 31 ayat (3) pemerintah mengusahakan dan menyelenggarakan satu sistem pendidikan nasional yang meningkatkan keimanan dan ketaqwaan serta akhlak mulia dalam rangka mencerdaskan kehidupan bangsa yang diatur dengan undang-undang.

2. Undang-Undang Nomor 23 Tahun 2002 tentang Perlindungan Anak, 3) Undang-Undang Nomor 20 tahun 2003 tentang Sistem Pendidikan Nasional, pasal 4, 9, dan pasal 11. Pasal 4, setiap anak berhak untuk dapat hidup, tumbuh, berkembang, dan berpatisipasi secara wajar sesuai dengan harkat dan martabat kemanusiaan, serta mendapat perlindungan dari kekerasan dan diskriminasi. Pasal 9, ayat (1) setiap anak berhak memperoleh pendidikan dan pengajaran dalam rangka pengembangan pribadinya dan tingkat kecerdasannya sesuai dengan minat dan bakatnya, ayat (2) selain hak anak sebagaimana dimaksud pada ayat (1) khusus bagi anak yang menyandang cacat juga berhak memperoleh pendidikan luar biasa, sedangkan bagi anak yang memiliki keunggulan juga berhak mendapatkan pendidikan khusus.

3. Undang-Undang Nomor 20 tahun 2003 tentang Sistem Pendidikan Nasional. Pasal 5 ayat (1) setiap warga negara mempunyai hak yang sama untuk memperoleh pendidikan yang bermutu. Pasal 28 ayat (1) pendidikan anak usia dini diselenggarakan sebelum jenjang pendidikan dasar, (2) Pendidikan Anak Usia Dini dapat diselenggarakan melalui jalur pendidikan formal, non formal, dan/atau informan, (3) Pendidikan Anak Usia Dini jalur pendidikan formal, TK, RA, atau bentuk lain yang sederajat, (4) Pendidikan Anak Usia Dini jalur pendidikan non formal, KB, TPA, atau bentuk lain yang sedarajat, (5) pendidikan usia dini jalur pendidikan informal, pendidikan keluarga atau pendidikan yang diselenggarakan oleh lingkungan.

\section{METODE PENELITIAN}

Penelitian ini merupakan penelitian deskriptif dengan studi kasus di Raudhatul Atfhal (RA) Perwanida 1 Lipu Kabupaten Majene Provinsi Sulawesi Barat. Jenis data yang diperlukan adalah data sekunder dan data primer. Data skunder diperoleh melalui kajian pustaka, yaitu melalui buku, jurnal dan catatan yang berhubungan masalah pendidikan terutama masalah bentukbentuk pembelajaran nilai agama di anak usia dini. Data primer diperoleh melalui, a) wawancara mendalam dengan informan, baik informan kunci maupun informan biasa tentang pembelajaran, b) teknik dokumentasi, dilakukan untuk menjaring data yang berhubungan dengan silabus, Rencana Kegiatan Mingguan (RKM), dan Rencana Kegiatan Harian (RKH) c) untuk melengkapi hasil wawancara dilakukan observasi terlibat terutama yang berhubungan dengan strategi/teknik/ langkah-langkah dalam proses pembelajaran atau seperti yang dimuat dalam RKH.

Penelitian ini menggunakan pendekatan kualitatif sehingga pengolahan data dilakukan dengan memperhatikan data yang sejenis dan data yang memiliki perbedaan antara satu dengan lain. Kemudian diidentifikasi keterkaitan data tersebut, terutama faktor yang menghubungkannya dan interpretasi data dilakukan tanpa mengabaikan data emik dan etik. Analisis dan pengolahan data disesuaikan dengan sifatnya, terutama dari hasil wawancara bebas diolah secara kualitatif sesuai dengan jenis data dan tujuan penelitian.

\section{PEMBAHASAN \\ Profil Raudhatul Atfhal Perwanida 1 Lipu}

Raudhatul Atfhal Perwanida 1 Lipu didirikan pada tahun 1979 oleh Yayasan Dharma Wanita Unit Agama Kabupaten Majene (Yayasan Perwanida) dengan ketua yayasan ibu Hanifiah Hamusta, BA dan sekeretaris ibu Yusran Djuaeni. Kedua pengurus ini merupakan pengagas sekaligus pendiri Yayasan Perwanida tersebut. Pendirian RA Perwanida 1 Lipu oleh Yayasan Dharma Wanita Unit Agama ini didasari oleh ide cemerlang para pendirinya yang ingin membantu usaha pemerintah dalam mensukseskan program pemerataan pendidikan.

Terhitung mulai tanggal 08 Pebruari 1979 Yayasan Perwanida (Dharma Wanita) unit Agama mensahkan berdirinya Raudhatul Atfhal (RA) Perwanida (Dharma Wanita) Unit Agama 1 yang secara operasional bertanggung jawab kepada pengurus Perwanida (Dharma wanita) Unit 
Agama Kabupaten Majene. Eksistensinya di dunia Pendidikan Anak Usia Dini dalam bentuk Raudhatul Atfhal (RA) selama \pm 30 tahun cukup dirasakan oleh masyarakat Majene, hal ini ditandai peserta didiknya dari tahun ke tahun semakin bertambah.

Raudhatul Athfal Perwanida 1 Lipu Kabupaten Majene merupakan lembaga pendidikan yang berstatus swasta yang dikelola oleh yayasan Dharma Wanita Kementerian Agama yang memiliki gedung yang sudah berstatus milik sendiri. Kurikulum yang diterapkan menggunakan kurikulum KTSP (Kurikulum Tingkat Satuan Pendidikan) yang bersumber dari dua kurikulum yang dikombinasikan yaitu kurikulum Kementerian Agama dan kurikulum Kementerian Pendidikan dan Kebudayaan. Kegiatan belajar di Raudhatul Athfal Perwanida 1 Lipu Kabupaten Majene dilaksanakan dalam seminggu, yaitu hari Senin sampai hari Sabtu dan berlangsung dari pukul 07.00 sampai 10.00 WIB. Lokasi Raudhatul Atfhal Perwanida 1 Lipu yang beralamat di Jalan Abd. Azasi Lipu No. 09, Kelurahan Labuang, Kecamatan Banggae Timur, Kabupaten Majene, Provinsi Sulawesi Barat.

Visi yang ingin di wujudkan oleh Raudhatul Atfhal Perwanida 1 Lipu ini adalah: "Terwujudnya peningkatan dan pemerataan pelayanan pendidikan terhadap terhadap semua peserta didik Raudhatul Atfhal Perwanida 1 Lipu yang bermutu, efektif, efesien, dan mandiri dengan meningkatkan peran serta orang tua peserta didik dan masyarakat dalam rangka desentralisasi pendidikan".

Untuk mewujudkan visi tersebut, maka Raudhatul Atfhal Perwanida 1 Lipu menjabarkan kedalam beberapa Misi diantaranya: a) Mengupayakan perluasan dan keempatan dalam merekrut calon siswa dan memperoleh pendidikan yang bermutu pada semua anak usia pra sekolah. b) Meningkatkan kualitas proses pendidikan supaya membentuk kepribadian Raudhatul Atfhal Perwanida 1 Lipu Majene secara optimal, bermoral, agamis, menguasai ilmu pengetahuan dan keterampilan hidup. c) Meningkatkan profesionalisme dan akuntabilitas Raudhatul Atfhal Perwanida 1 Lipu dengan menjalankan fungsi secara maksimal. d) Memberdayakan peran masyarakat dalam menyelenggarakan pendidikan Raudhatul Atfhal Perwanida 1 Lipu yang efektif dan efesien berdasarkan prinsif kemandirian dalam rangka otonomi daerah di bawah naungan Yayasan Persatuan Dharma Wanita Departemen Agama Kabupaten Majene.

\section{Penyelenggaraan Pendidikan Agama di Raudhatul Atfhal Perwanida 1 Lipu}

Pendekatan keagamaan dalam pendidikan anak dimaksudkan adalah bagaimana cara pendidik memproses anak didik melalui kegiatan bimbingan, latihan atau pengajaran keagamaan, termasuk di dalamnya mengarahkan, mendorong dan memberi semangat kepada anak agar taat dan mempunyai cita rasa beragama Islam, untuk mencapai tujuan pendidikan pada anak TK tersebut. Dengan kata lain bahwa perkembangan agama pada anak sangat ditentukan oleh pendidikan dan pengalaman yang di laluinya terutama pada masa-masa pertumbuhan yang pertama (masa anak) dari umur 0-12 tahun. Masa ini merupakan masa yang sangat menentukan bagi pertumbuhan dan perkembangan agama anak untuk masa berikutnya.

Pendidikan keagamaan pada anak lebih bersifat teladan atau peragaan hidup secara riil, dan belajar dengan cara meniru-niru, menyesuaikan dan mengintegrasi diri dalam suatu suasana. Karena itu latihan-latihan keagamaan dan pembiasaannya itulah yang harus lebih ditonjolkan, misalnya latihan ibadah sholat, doa, membaca Alquran, menghafalkan ayat-ayat pendek, sholat berjamaah di musholla atau masjid, latihan dan pembiasaan akhlak.

Implementasi penanaman nilai-nilai agama pada siswa di RA Perwanida 1 Lipu dituangkan dalam proses pembelajaran yang mencakup kegiatan awal, kegiatan inti, dan kegiatan akhir. Penjabaran dari pada indikator-indikator perkembangan anak akan di lihat pada implementasinya diproses pembelajaran. Guru dalam melakukan pembelajaran dikelas selalu memberikan muatan agama pada setiap kegiatan dengan mengintegrasikan ke dalam kelompok program pembelajaran yang terdiri dari beberapa lingkup perkembangan anak yang meliputi: lingkup perkembangan nilai-nilai agama dan moral, fisik, yaitu perkembangan motorik halus dan motorik kasar, kognitif, bahasa, dan sosial emosional.

Penyelenggaraan pendidikan agama yang di implementasikan oleh RA Perwanida 1 Lipu Kabupaten Majene dapat diungkap melalui komponen/instrumen pembelajaran yang meliputi kurikulum, metode dan model pembelajaran, serta sistem evaluasi yang diterapkan. Oleh karena itu, akan di uraikan kondisi riil setiap komponen/ instrumen pendidikan di RA Perwanida 1 Lipu sebagai berikut: 


\section{Kurikulum}

Kurikulum merupakan seperangkat rencana dan pengaturan mengenai tujuan, isi dan bahan kegiatan atau pelajaran serta cara yang digunakan sebagai pedoman peyenggaraan kegiatan pembelajaran untuk mencapai tujuan pendidikan. Sebagaimana diketahui bahwa kurikulum memegang kedudukan kunci dalam pendidikan, sebab berkaitan dengan penentuan arah, isi, dan proses pendidikan dan bermuara pada penentuan dan kualifikasi kelulusan suatu lembaga pendidikan. Kurikulum menyangkut rencana dan pelaksanaan pendidikan baik dalam lingkup kelas, sekolah, daerah, wilayah, maupun nasional. Oleh sebab itu, pengembangan kurikulum di Indonesia disesuaikan dengan potensi, perkembangan, kepentingan dan kebutuhan para siswa serta lingkungannya karena siswa merupakan pelaku pendidikan secara langsung dan diharapkan upaya yang optimal serta komitmen yang tinggi dari para pendidik maupun pengambil kebijakan agar dapat mengimplementasikan isi kurikulum di dalam kegiatan pembelajarannya secara rinci dan terarah. Sehubungan dengan itu penerapan Kurikulum yang saat ini diberlakukan/ dipakai di Raudhatul Atfhal Perwanida 1 Lipu adalah kurikulum yang diterbitkan oleh Dinas Pendidikan dan Kementerian Agama yang di kombinasikan. Perangkat pembelajaran yang dikembangkan di Raudhatul Atfhal (RA) Perwanida 1 Lipu terdiri atas:

\section{Perencanaan Semester}

Perencanaan semester merupakan program pembelajaran yang berisi jaringan tema, bidang pengembangan/lingkup perkembangan, indikator dan alokasi waktu. Adapun langkahlangkah pengembangan program semester, yaitu mempelajari dokumen kurikulum, menentukan tema yang akan digunakan dalam setiap semester dan menetapkan alokasi waktu untuk untuk setiap tema, mengidentifikasi tema menjadi sub tema dan menyusun program semester dengan cara tema-tema yang dipilih dan hasil identifikasi tema menjadi sub tema dibuat dalam bentuk tabel.

Alternatif tema-tema yang dipilih dalam proses pembelajaran untuk setiap semester berikut alokasi waktunya di Raudhatul Atfhal (RA) Perwanida 1 Lipu Kabupeten Majene adalah lihat tabel 1.
Tabel 1: Program Pembelajaran RA Perwanida 1 Lipu

\begin{tabular}{llllll}
\hline & \multicolumn{2}{c}{ SEMESTER I } & \multicolumn{3}{c}{ SEMESTER II } \\
No & Tema & Waktu & No & Tema & Waktu \\
\hline 1 & Diri Sendiri & 3 Pekan & 1 & Rekreasi & 4 Pekan \\
2 & Lingkunganku & 4 Pekan & 2 & Pekerjaan & 3 Pekan \\
3 & Kebutuhanku & 4 Pekan & 3 & Air, Udara dan & 2 Pekan \\
4 & Binatang & 3 Pekan & 4 & Alat Komunikasi & 2 Pekan \\
5 & Tanaman & 3 Pekan & 5 & Tanah Airku & 3 Pekan \\
Jumlah & 17 Pekan & 6 & Alam Semesta & 3 Pekan
\end{tabular}

Sumber: Kurikulum RA Perwanida 1 Lipu tahun 2012

\section{Rencana Kegiatan Mingguan (RKM)}

RKM merupakan penjabaran dari perencanaan semester yang berisi kegiatan-kegiatan dalam rangka mencapai indikator yang telah di rencanakan dalam satu minggu sesuai dengan keluasan pembahasan tema dan sub tema.

Gambar 1: Rencana Kegiatan Mingguan RA Perwanida 1 Lipu

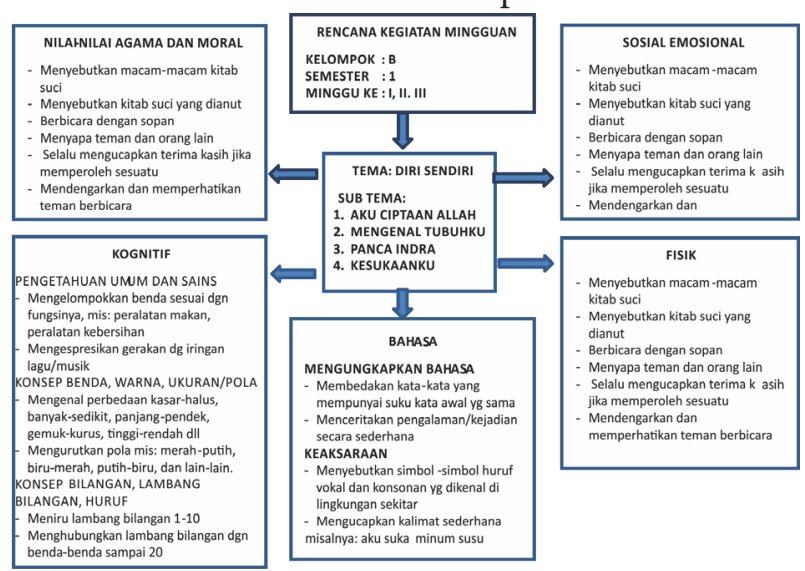

Sumber: Kurikulum RA Perwanida 1 Lipu tahun 2012 (diolah)

\section{Rencana Kegiatan Harian (RKH)}

Rencana Kegiatan Harian (RKH) merupakan penjabaran dari Rencana Kerja Mingguan (RKM) yang memuat kegiatan-kegiatan pembelajaran baik yang dilaksanakan secara individu, kelompok, maupun klasikal dalam satu hari. RKH terdiri atas kegiatan awal, kegiatan inti, istirahat, dan kegiatan akhir.

Secara garis besar bentuk penanaman nilainilai agama yang diterapkan oleh Raudhatul Atfhal Perwanida 1 Lipu yang terjabarkan dalam proses pembelajaran yang terbagi dalam tiga tahapan pembelajaran yaitu: 
Kegiatan Awal Pembelajaran. Kegiatan yang dilakukan pada awal pembelajaran yang durasinya kurang lebih 30 menit dengan menitik beratkan pada menanamkan pembiasaan kepada siswa untuk selalu berprilaku yang baik seperti berprilaku disiplin, sabar, dan mandiri, serta menanamkan pembiasaan nilai-nilai ahklak mulia bagi siswa sejak dini seperti berbicara, bersikap, dan berprilaku yang mulia dalam kehidupan sehari-hari. Adapun materi-materinya sebagai berikut:

\section{Salam dan Pembacaan Doa Sebelum Melakukan Kegiatan}

Materi-materi yang berkaitan dengan penanaman nilai-nilai agama dan moral yang tertuang dalam kegiatan awal ini tentunya dimulai dengan membiasakan siswa untuk selalu mengucapkan salam dan dilanjutkan dengan pembacaan doa sebelum memulai proses pembelajaran. Doa yang lazim di praktekkan adalah doa belajar yang di berikan secara kontinyu setiap hari sehingga semua siswa baik dikelas A maupun di kelas B sudah menghafalnya dengan baik dan fasih. Pembacaan doa di lakukan di dalam kelas yang dipimpin oleh guru pembimbing yang selanjutnya secara bergiliran menunjuk salah seorang siswa untuk tampil kedepan untuk memimpin pembacaan doa tersebut, dan kegiatan ini dilakukan secara berulang setiap hari dengan metode yang sama.

\section{Bernyanyi}

Kegiatan bermain dan bernyanyi merupakan kegiatan yang sangat menyenangkan bagi anak-anak, sehingga sebelum melakukan kegiatan pembelajaran siswa disuguhkan nyanyian yang bernuansa islami untuk memberikan motivasi kepada siswa agar bergairah menerima materi pelajaran. Biasanya nyanyian-nyanyian yang dilantunkan oleh siswa di Raudhatul Atfhal Perwanida 1 Lipu yang sempat peneliti amati secara langsung di kelas A1 seperti, nyanyia "Siapa Tuhanmu, Islam Agamaku, dan Tamasya versi Islam".

\section{Menghafal Surat-Surat Pendek}

Untuk memberikan penanaman nilai-nilai agama pada siswa di Raudhatul Atfhal Perwanida 1 Lipu juga memberikan pengenalan pelajaran Alquran sejak dini secara klasikal dengan harapan para siswa dapat menghafal beberapa surat-surat dalam Alquran utamanya surat-surat pendek dan terjemahannya seperti: Surat Al-Fatihah, Al-Ikhlas, An-Nas, Al-Falaq, An-Nasr, dan sebagainya.

\section{Kegiatan Inti Pembelajaran}

Kegiatan inti merupakan rangkaian proses kegiatan belajar mengajar dengan durasi waktu kurang lebih 60 menit. Muatan materi penanaman nilai-nilai agama yang diberikan selama kegiatan pembelajaran tersebut menyangkut pelajaran Alquran, fiqih, aqidah, dan doa-doa untuk sehari-hari. Kegiatan keagamaan yang di berikan kepada siswa bertujuan untuk menanamkan perilaku religius sejak dini kepada siswa sehingga menjadi pembiasaan yang baik, sehingga mampu meningkatkan ketaqwaan siswa kepada Allah swt, agar menjadi pribadi yang saleh di masa-masa yang akan datang.

Praktek-praktek keagamaan yang dilakukan di Raudhatul Atfhal Perwanida 1 Lipu sebagai pembiasaan terdiri dari beberapa aspek pelajaran antara lain:

Pelajaran Fiqih. Fiqih adalah salah satu bidang ilmu dalam syariat Islam yang secara khusus membahas persoalan hukum yang mengatur berbagai aspek kehidupan manusia, baik kehidupan pribadi, bermasyarakat maupun kehidupan manusia dengan Tuhannya. Beberapa ulama fikih seperti Imam Abu Hanifah mendefinisikan fikih sebagai pengetahuan seorang muslim tentang kewajiban dan haknya sebagai hamba Allah. Fiqih membahas tentang bagaimana cara beribadah, tentang prinsip Rukun Islam dan hubungan antar manusia sesuai dengan dalil-dalil yang terdapat dalam Alquran dan Sunnah.

Pelajaran ilmu fiqih yang di berikan guru pembimbing kepada siswa mencakup aspek ibadah seperti:

Pelajaran Berwudhu. Kegiatan ini di lakukan dalam bentuk teori dan praktek. ada tiga tahap pembelajaran teori yang diberikan mulai dari memberikan penjelasan kepada siswa tentang rukun wudhu yang terdiri dari niat, membasuh muka, membasuh kedua tangan sampai siku, mengusap sebagain kepala, membasuh kaki sampai mata kaki, dan dilakukan dengan tertib atau teratur. Setelah siswa memahami tentang rukun wudhu, dilanjutkan dengan melafazkan niat wudhu, serta doa setelah berwudhu. Kegiatan praktek berwudhu biasanya dilakukan di luar kelas dengan menggunakan media ember yang di isi air. Para siswa melakukan praktek berwudhu secara bergiliran yang dipantau oleh guru pembimbing untuk melakukan evaluasi atau penilaian. Bagi siswa yang belum melakukan tata cara berwudhu dengan baik akan diberikan 
penjelasan ulang oleh guru pembimbing sampai mampu untuk melakukannya.

Pelajaran Shalat. Sama halnya dengan pelajaran berwudhu, pelajaran shalat pun dilakukan dalam dua tahap pelajaran yaitu teori dan praktek. Tahapan-tahapan yang diberikan pada teori pelajaran shalat terdiri dari: Bacaan niat shalat fardhu (Isya, Subuh, Dzuhur, Ashar, dan Magrib), bacaan takbiratul ihram, doa iftitah, surat AlFatihah, surat pendek dari Alquran, ruku, i'tidal, sujud, duduk diantara dua sujud, sujud ke dua, tasyahud awal, tasyahud akhir, dan diakhiri dengan ucapan salam. Untuk kegiatan prakteknya biasanya siswa di informasikan agar membawa perlengkapan shalat seperti sarung, songkok, mukenah, sajadah, dan sebagainya. Hal ini dilakukan karena pihak sekolah tidak menyediakan alat praktek shalat, dan tidak memilik ruangan (mushallah) yang representatif untuk melakukan kegiatan praktek shalat tersebut. Sehingga kegiatan praktek shalat dilakukan di dalam kelas saja yang ukurannya tidak terlalu luas. keterbatasan inilah yang membuat para guru pembimbing merasa tidak maksimal dalam memberikan bimbingan pelaksanaan praktek shalat tersebut.

Pelajaran Aqidah. Secara terminologi: akidah adalah iman yang teguh dan pasti, yang tidak ada keraguan sedikit pun bagi orang yang meyakininya. Yaitu perkara yang wajib dibenarkan oleh hati dan jiwa menjadi tenteram karenanya, sehingga menjadi suatu kenyataan yang teguh dan kokoh, yang tidak tercampuri oleh keraguan dan kebimbangan. Dengan kata lain, keimanan yang pasti tidak terkandung suatu keraguan apapun pada orang yang menyakininya. Dan harus sesuai dengan kenyataannya; yang tidak menerima keraguan atau prasangka. (http://alislamu.com/aqidah/683definisi-aqidah.html).

Aspek aqidah yang dipraktekkan di Raudhatul Atfhal Perwanida 1 Lipu meliputi;

Kalimat-kalimat Thayyibah, mislanya ucapan Basmalah (Bismillahir rahmanir rahim). Membiasakan siswa untuk selalu mengucapkan basmalah. Ucapan basmalah dipraktekkan kepada siswa pada saat setiap melakukan suatu kegiatan, sehingga siswa dapat terbiasa dalam mengucapkan bacaan masmalah tersebut. Ucapan Hamdalah (Alhamdu lillahi rabbil álamin). Ucapan ini dipraktekkan kepada siswa dikala memperoleh atau mendengarkan kabar mengembirakan/ membahagian (suka cita). Sebagai ungkapan rasa syukur atas semua keberkahan tersebut maka di ucapkan kalimat hamdalah. Ucapan Syahadat
(Asyhadu an la ilaha illallahu wa asyhadu anna muhammadar rasulullah). Merupakan asas dan dasar dari lima rukun Islam dan merupakan ruh, inti dan landasan seluruh ajaran Islam. Sebuah pernyataan kepercayaan dalam keesaan Tuhan (Allah) dan Nabi Muhammad sebagai Rasul-Nya. Ucapan Istighfar (Astagfirullahal 'azhim). Ucapan ini di praktekkan kepada siswa jikalau keliru atau berbuat kesalahan (lalai dalam melakukan sesuatu).

Mengenalkan nama-nama Allah swt (Asmaul Husna). Asmaul husnah adalah namanama Allah yang indah dan baik. Cara mengenalkan nama-nama Allah swt dengan membiasakan anak menyebutkan salah satu atau beberapa dari 99 Asmaul Husna (nama-nama Allah) tersebut, di samping itu di perkenalkan Asmaul Husna lewat lagu seperti Al-Kholiq yang artinya Allah maha pencipta.

Mengenalkan nama-nama Malaikat Allah. Guru memberikan penanaman aqidah pada siswa terhadap para malaikat Allah yang berjumlah 10 beserta tugas yang diembannya yaitu: Malaikat Jibril tugasnya menyampaikan wahyu, Malaikat Mikail bertugas membagi rezki, Malaikat Israfil bertugas meniup sangkakala, Malaikat Israil tugasnya mencabut nyawa, Malaikat Munkar bertugas menjaga kubur, Malaikat Nakir bertugas menjaga kubur, Malaikat Raqib bertugas mencatat amal kebaikan, Malaikat Atid bertugas mencatat amal keburukan, Malaikat Malik bertugas menjaga neraka, Malaikat Ridwan bertugas menjaga surga.

Mengenalkan nama-Nama Nabi dan Rasul. Guru mengenalkan para Nabi dan Rasul Allah yang berjumlah $25 \mathrm{Nabi/Rasul} \mathrm{mulai} \mathrm{dari} \mathrm{Nabi/Rasul}$ pertama yaitu Nabi Adam as, sampai kepada Nabi yang terakhir yaitu Nabi Muhammad saw.

Mengucapkan Syair Islam. Mislnya dalam bentuk pengakuan/sumpah seperti dalam bentuk syair-syair: Dengarkanlah sumpahku, Asyhadu an la ilaha illallahu wa asyhadu anna muhammadar rasulullah, Tuhan Allah Tuhanku, Muhammad Nabiku, Agama Islam Agamaku, kita patut menyembah 5 kali sehari semalam shubuh, dzuhur, ashar, magrib, isya.

Mengenalkan Huruf-Huruf Hijaiyah. Seperti mencocokkan huruf-huruf hijaiyah dengan media stempel, menunjukkan dan menulis hurufhuruf hijaiyah sesuai perintah guru pembimbing, menciplak dan meniru huruf hijaiyah dengan media gambar huruf hijaiyah dan lain sebagainya.

Mengenalkan Huruf. Misalnya angka 1 sampai 10 dengan bahasa arab seperti wahidun, 
isnaini, tsalasatun, arba'antun, hamsatun, sittatun, tsamaniatun, tis'atun, asyaratun.

Mengenalkan Nama Bulan. Nama-nama bulan qamariah seperti; bulan Muharram, Safar, Rabiul Awal, Rabiul Akhir, Jumadil Awal, Jumadil Akhir, Rajab, Sya'ban, Ramadhan, Syawal, Zulhajji, dan Zulkaidah.

Mengenalkan macam-macam agama dan tempat ibadanya yang ada di Indonesia. Dan mengenal ciptaan Tuhan yang ada di langit (bulan, bintang, awan, matahari), yang ada di laut (ikan, kerang, cumi-cumi), yang ada di darat (jenis tumbuhan, jenis hewan) dan lain sebagainya.

Pelajaran Alquran. Untuk memberikan penanaman nilai-nilai agama pada siswa di Raudhatul Atfhal Perwanida 1 Lipu juga memberikan pengenalan pelajaran Alquran sejak dini secara klasikal dengan harapan para siswa dapat menghafal beberapa surat-surat dalam Alquran utamanya surat-surat pendek dan terjemahannya seperti: Surat Al-Fatihah, Al-Ikhlas, An-Nas, AlFalaq, An-Nasr, dan sebagainya.

Pelajaran Doa Sehari-hari. Ada beberapa doa sehari-hari yang di tanamkan guru pembimbing kepada siswa sebagai wujud pembiasaan yang baik dengan tujuan agar dapat tertanam di hati sanubari siswa dalam berperilaku dikehidupan kesehariannya. Doa sehari-hari yang dipraktekkan dalam proses pembelajaran seperti: Doa sebelum dan sesudah pembelajaran, Doa sebelum dan sesudah makan, doa masuk dan keluar WC, doa sebelum dan sesudah tidur, doa untuk kedua orang tua, doa kebaikan dunia akhirat, dan sebagainya.

Kegiatan Akhir (penutup). Setelah proses kegiatan pembelajaran inti selesai maka dipersilahkan siswa untuk istirahat selama 30 menit, kegiatan yang dilakukan selama istirahat itu mengajak siswa untuk makan dan bermain. Selama proses istirahat tersebut dibiasakan siswa untuk selalu mencuci tangan dahulu dan berdo'a sambil bernyanyi, selanjutnya melakukan kegiatan bermain dengan media permainan seperti ayunan, luncuran, kuda-kudaan dan lain sebagainya.

Aktifitas yang dilakukan oleh siswa pada saat kegiatan akhir proses pembelajaran yaitu: tanya jawab; Guru pembimbing mengulang kembali pelajaran yang yang telah diberikan kepada siswa dengan metode tanya-jawab tentang kegiatan pembelajaran selama sehari. Kegiatan ini bertujuan untuk merefleksikan kembali memori siswa terhadap peristiwa-peristiwa yang telah siswa alami, sekaligus sebagai evaluasi sejauhmana siswa dapat menerima pelajaran dengan baik. Bernyanyi; kegiatan bernyanyi diakhir pembelajaran bertujuan untuk memberikan keceriaan kepada siswa setelah menerima pelajaran. Nyanyian yang dilantunkan biasanya disesuaikan dengan tema pelajaran, karena temanya menyangkut diri sendiri sehingga lagu yang dipilih yang berkaitan dengan panca indera seperti lagu "dua mata saya, aku sayang ibu". Membaca doa setelah melakukan kegiatan dan ditutup dengan mengucapkan salam. Khusus untuk doa-doa yang praktekkan pada saat mau pulang seperti doa kedua orang tua, doa keselamatan, doa sebelum tidur, dan doa keluar pintu.

\section{Metode dan Model Pembelajaran}

Menurut pandangan filsafat pendidik metode merupakan alat yang digunakan untuk mencapai tujuan pendidikan. Penggunaan metode pembelajaran implikasinya bersifat konsisten dan sistematis karena sasaran metode adalah manusia yang sedang mengalami perubahan dan perkembangan, yang menurut $\mathrm{H}$. Horne metode dalam pendidikan merupakan suatu prosedur dalam mengajar (Rahim, 2006:20).

Metode pendekatan pembelajaran yang dipakai atau diterapkan oleh tenaga pendidik (guru) di RA Perwanida 1 Lipu Kabupaten Majene masih tetap memakai kedua pola pendekatan yaitu Teacher Centered (pendekatan yang berpusat pada guru), dan pendekatan Student Centered (pendekatan yang berpusat pada siswa).

Metode pembelajaran adalah cara yang dilakukan guru dalam membimbing peserta didik (siswa) mencapai kompetensi yang ditetapkan. Metode pembelajaran yang biasa di terapkan oleh guru pembimbing di Raudhatul Atfhal (RA) Perwanida $1 \mathrm{Lipu}$ terdiri dari beberapa metode diantaranya: metode bercerita, metode bercakapcakap, metode bermain peran, metode demonstrasi, metode tanya jawab, dan metode pemberian tugas.

Model pembelajaran adalah suatu desain atau rancangan yang menggambarkan rincian dan penciptaan situasi lingkungan yang memungkinkan siswa dapat berintraksi dalam pembelajaran, sehingga terjadi perubahan atau perkembangan pada diri siswa. Penyusunan model pembelajaran di Raudahtul Atfhal Perwanida 1 Lipu tetap merujuk pada silabus yang dikembangkan dalam kegiatan Perencanaan Semester, Rencana Kegiatan Mingguan (RKM), dan Rencana Kegiatan Harian (RKH). Oleh karena itu, model pembelajaran yang di lakukan oleh guru pembimbing di Raudhatul 
Atfhal Perwanida 1 Lipu harus disesuaikan dengan Rencana Kegiatan Harian.

Sesuai dengan kurikulum RA/BA/TA Kementerian Agama RI yang diterbitkan oleh Direktorat Pendidikan Madrasah, Direktorat Jenderal Pendidikan Islam tahun 2011, menyebutkan bahwa ada beberapa model pembelajaran yang bisa dilaksanakan di pendidikan anak usia dini diantaranya adalah: model pembelajaran klasikal, model pembelajaran kelompok, model pembelajaran sudut, model pembelajaran area, dan model pembelajaran sentra.

Sesuai dengan kurikulum RA/BA/TA Kementrian Agama RI yang diterbitkan oleh Direktorat Pendidikan Madrasah, Direktorat Jenderal Pendidikan Islam tahun 2011, (Direktorat Pendidikan Madrasah, 2011:18), menyebutkan bahwa ada beberapa beberapa model pembelajaran yang bisadilaksanakan di pendidikan anak usia dini, namun menurut beberapa guru pembimbing yang sempat dimintai keterangannya menyebabkan hanya model pembelajaran sudut yang selalu diterapkan.

Kegiatan belajar mengajar dengan model pembelajaran sudut-sudut kegiatan menggunakan beberapa sudut kegiatan seperti: a) Sudut ketuhanan: Ada beberapa media atau gambar yang terpajang di sudut ketuhanan yang berhubungan dengan kegiatan-kegiatan keagamaan seperti; gambar atau miniatur masjid, gambar tata cara berwudhu, gambar tata cara shalat, huruf-huruf hijaiyah dan sebagainya. b) Sudut kekeluargaan: Gambar yang terpampang pada sudut kekeluargaan adalah gambar anggota keluarga seperti; gambar ayah, ibu, kakak, adik, kakek, nenek, dan bibi. c) Sudut kebudayaan: Ada beberapa media atau gambar yang ditampilkan pada sudut kebudayaan tersebut seperti; baju-baju adat, rumah adat, jenis tari-tarian daerah. d) Sudut pembangunan: Bentuk-bentuk sudut bangunan yang berkaitan dengan alat-alat pertukangan seperti; gergaji, palu, skop, kayu balok, kayu bentuk segi tiga, batu bata dan sebagainya. e) Sudut alam sekitar: Yang termasuk dalam kategori sudut alam sekitar meliputi; biji-bijian, macam-macam warna, binatang, tumbuh-tumbuhan, kerang-kerangan dan sebagainya.

\section{Sistem Evaluasi}

Kualitas pendidikan sangat ditentukan oleh kemampuan satuan pendidikan dalam mengelola proses pembelajaran. Penilaian merupakan bagian yang penting dalam pembelajaran. Dengan melakukan penilaian, pendidik sebagai pengelola kegiatan pembelajaran dapat mengetahui kemampuan yang dimiliki siswa, ketepatan metode mengajar yang digunakan, dan keberhasilan siswa dalam meraih kompetensi yang telah ditetapkan. Berdasarkan hasil penilaian, guru dapat mengambil keputusan secara tepat untuk menentukan langkah yang harus dilakukan selanjutnya. Hasil penilaian juga dapat memberikan motivasi kepada peserta didik untuk berprestasi lebih baik.

Evaluasi pembelajaran merupakan penilaian kegiatan dan kemajuan belajar siswa yang dilakukan secara berkala berbentuk ujian, praktikum, tugas, dan atau pengamatan guru. Bentuk ujian meliputi ujian tengah semester, ujian akhir semester, dan ujian tugas akhir.

Tujuan dari penilaian adalah untuk mengukur seberapa jauh tingkat keberhasilan proses belajar mengajar yang telah dilaksanakan oleh guru. Di samping itu penilaian juga bertujuan untuk mengetahui seberapa jauh keberhasilan guru dalam melaksanakan proses pembelajaran, yang digunakan sebagai umpan balik bagi guru dalam merencanakan proses pembelajaran selanjutnya (Trianto, 2010:254).

Menurut Permendiknas Nomor 58 Tahun 2009 tentang Standar Pendidikan Anak Usia Dini, penilaian adalah proses pengumpulan dan pengolahan informasi untuk menentukan tingkat pencapaian perkembangan anak. Bahasan penilaian sebagaimana tercantum dalam Permendiknas Nomor 58 Tahun 2009 tersebut mencakup 1) teknik penilaian, 2) lingkup penilaian, 3) proses penilaian, 4) pengelolaan hasil, dan 5) tindak lanjut hasil penilaian.

Pelaksanaan evaluasi yang diterapkan oleh guru di RA Perwanida 1 Lipu Kabupaten Majene dilakukan setelah siswa selesai proses pembelajaran pada satu pokok bahasan. Evaluasi yang diberikan oleh guru umumnya untuk mengetahui apakah tujuan pembelajaran tersebut telah tercapai atau belum, dan untuk mengetahui apakah pengetahuan sikap dan keterampilan telah benar-benar dimiliki oleh siswa atau belum.

Teknik penilaian yang dilakukan oleh guru di RA Perwanida 1 Lipu mengacu kepada Permendiknas No 58 Tahun 2009, teknik penilaian hasil belajar anak di RA Perwanida 1 Lipu Kabupaten Majene di lakukan dengan teknik, pengamatan (observasi), penugasan, unjuk kerja, percakapan, dan hasil karya. 


\section{PENUTUP}

Implementasi penanaman nilai-nilai pendidikan agama di Raudhatul Atfhal perwanida 1 Lipu telah berlangsung sejak lama yang dituangkan dalam proses pembelajaran yang mencakup kegiatan awal, inti dan penutup. Bentuk-bentuk pembelajaran nilai agama di kegiatan awal meliputi mengucapkan salam dan doa sebelum kegiatan pembelajaran, melantunkan nyanyian islami, serta melafazkan surat-surat pendek (juz Amma). Pada kegiatan inti bentuk pembelajaran agama meliputi pelajaran fiqhi (tata cara berwudhu dan shalat), pelajaran aqidah (pengenalan tentang kalimat thayyibah, asmaul husnah, nama-nama malaikat, nabi dan rasul Allah), pelajaran Alquran, dan pelajaran doa seharihari. Praktek-praktek keagamaan yang dilakukan pada kegiatan penutup antara lain melakukan tanya jawab terhadap materi yang telah disampaikan, pelantunkan syair-syair islami, dan berdoa seperti doa keselamatan, doa sebelum dan sesudah tidur, doa keluar pintu, dan doa untuk kedua orang tua. Penanaman nilai-nilai agama tersebut dilakukan dengan cara mengintegrasikan pada setiap bidang pengembangan yaitu; pengembangan nilai-nilai agama dan moral, pengembangan fisik-mototorik, pengembangan bahasa, pengembangan kognitif, dan pengembangan sosial emosional.

\section{UCAPAN TERIMA KASIH}

Tulisan ini selesai atas bantuan berbagai pihak. Olehnya itu, dengan kerendahan hati yang paling dalam saya ingin menghaturkan terima kasih kepada: Kepala Balai Penelitian dan Pengembangan Agama Makassar Dr. H. Kadir Massoweang, M.Ag yang telah memberikan kepercayaan kepada penulis untuk melakukan penelitian tentang PAUD di Kabupaten Majene. Kasi Mapenda Kemenag Kabupaten Majene bapak Drs. Muliadi, M.Pd beserta seluruh stafnya yang tidak bisa disebutkan satu persatu, yang telah membantu peneliti menyediakan data-data terkait dengan penelitian yang dilakukan. Kepala RA Perwanida $1 \mathrm{Lipu} \mathrm{ibu} \mathrm{Hj}$. Ramlah Thaha, S.PdI dan seluruh guru-guru yang meluangkan waktu selama peneliti berada dilokasi, penulis mengucapkan terima kasih atas imformasi yang telah diberikan. Demikian pula ucapan terima kasih penulis ucapkan kepada bapak Dr. Mahmud
Thoha, yang telah membimbing dan mengoreksi tulisan ini ketika penulis mengikuti Diklat Teknis Penulisan KTI yang di laksanakan oleh LIPI di Kota Manado.

\section{DAFTAR PUSTAKA}

Direktorat PAUD dalam Haedari. 2009. Rencana Induk (Master Plan), Pendidikan Agama Islam Pada Pendidikan Anak Usia Dini (PAUD) 2010-2014 di Propinsi DKI Jakarta.

Direktorat Pendidikan Madrasah, Direktorat Jenderal Pendidikan Islam. 2011. Kurikulum RA/BA/TA. Pedoman Pengembangan Program Pembelajaran, Pedoman Pengembangan Silabus, Pedoman Penilaian, Kementerian Agama RI.

http://alislamu.com/aqidah/683-definisi-aqidah. html. Diunduh pada hari Rabu, tanggal 17 Oktober 2012

http://repository.upi.edu/operator/upload/t bp 999624 chapter1.pdf. Diunduh pada hari Kamis, tanggal 18 Oktober 2012

http://repository.upi.edu/operator/upload/t pendas_0808974_chapter2.pdf. Diunduh pada hari Rabu, tanggal 17 Oktober 2012.

Kementerian Agama RI. 2011. Kurikulum RA/BA/ TA. Direktorat Jenderal Pendidikan Islam. Direktorat Pendidikan Madrasah.

Murdiono, Mukhamad. 2009. Metode Penanaman Nilai Moral untuk Anak Usia Dini. Yogyakarta: Universitas Negeri Yokyakarta.

Permendiknas Nomor 58 Tahun 2009. tentang Standar Pendidikan PAUD.

Rahim, Husni dkk. 2006. Kendali Mutu Pendidikan Agama Islam. Cet I. Departemen Agama RI. Direktorat Jenderal Pembinaan Kelembagaan Islam.

Rantina, Mahyumi. 2012. Pembelajaran Agama di Sentra Iman dan Taqwa Taman KanakKanak Huffazh Payakumbuh. Jurnal Pesona PAUD Vol. 1 No. 1. Universitas Negeri Malang.

Trianto, 2010. Mendesain Model Pembelajaran Inovatif-Progresif. Cet II. Jakarta: Kecana Prenada Media Grup.

UU Nomor 20 Tahun 2003. Tentang Sistem Pendidikan Nasional Pasal 1 ayat 4. 